\title{
»Man tager virkeligheden og gør den til en god historie«
}

\author{
Af Birgitte Knudsen
}

\begin{abstract}
I MedieKultur nr. 30 udskrev redaktionen en konkurrence om "den bedste artikel om Robinson Ekspeditionen." Deadline for besvarelser var d. 1.1 2001, og Birgitte Knudsens bidrag er belonnet med vin og publicering i dette nummer af MedieKultur, hvor reality-tv er tema. De øvrige artikler om Robinson Ekspeditionen i nervarende nummer er indkommet efter deadline og har ikke deltaget $i$ konkurrencen.
\end{abstract}

\begin{abstract}
Artiklen gennemgår de resultater, som fremkom på baggrund af en undersøgelse af Robinson Ekspeditionen år 2000. Det empiriske grundlag udgøres af to fokusgrupper - begge med stort kendskab til Robinson Ekspeditionen. Analysen viser, at deltagerne i fokusgrupperne opfatter Robinson Ekspeditionen som et underholdningsprogram og som et spil. Samtidig opfattes deltagerne i ekspeditionen som virkelige mennesker, som foretager virkelige handlinger, og det betragtes hverken som et problem, at TV3 har castet dem som figurer med bestemte karakteristika, eller at programmerne er redigeret på fiktionelle premisser. Analysen peger hermed på, at TV3 har indgået en succesfuld dobbelt kontrakt med seriens trofaste seere: det betyder ikke så meget med nuancerne $i$ iscenesattelsesgraden og dermed virkelighedsreferencen - når bare programmet opfylder sin mission: at underholde seeren med intriger og alliancer mellem virkelige mennesker.
\end{abstract}

»Man tager virkeligheden og gør den til en god historie«. Dette citat synes at rumme nøglen til TV3's seertalssucces Robinson Ekspeditionen, der for tredje år i træk har været en stor succes for TV3. De tretten afsnit af ø-historien har i løbet af den tid, de er blevet sendt, ligget blandt de absolut mest sete programmer i landet. Anne Jerslev har i flere artikler i dette efterår defineret Robinson Ekspeditionen som et eksempel på reality-tv. Denne artikel ser i en receptionsanalyse på, hvordan seerne oplever denne form for tv, som er en hybrid mellem fiktion og fakta.

Virkelighed eller løgn. Autenticitet eller konstruktion. Robinson Ekspeditionen er ét eksempel på at 'virkeligheden' maser sig på i tv-billedet i disse år, og at interessen for realismen, for det dokumentariske og for at blive tilbudt positionen som Øjenvidne til et udsnit af virkeligheden, er stor. Reality-tv dækker over en række forskellige former der dog alle har hybriditeten og en bestræbelse på at etablere autenticitet til fælles. (Jerslev 2000)

I reality-tv programmer oplever seerne tilsyneladende begivenhederne i det øjeblik, de sker. Men samtidig lægges der i programmet ikke skjul på, at det er efterredigeret. Dermed er det vanskeligt at gennemskue, hvad der virkelig er sket, hvad der er iscenesat, og hvad der er lagt til i efterredaktionen. Hvad tænker seerne egentlig om dette, og skal fascinationskraften findes i det autentiske, realistiske islæt eller i de træk i programmet, som ligner fiktionsseriens? Robinson Ekspeditionen er samtidig eksponent for den nye type af tv-programmer, der skaber en egen virtuel virkelighed, en art eget medierum med begivenheder, der udspiller sig i formiddagspressen, i radio og i billedbladene, og som langsomt bliver en del af det almindelige offentlige rum. TV3 formår at sætte dagsorden i aviser, blade og andre tv- og radioprogrammer, hvor deltagerne optræder under og efter, serien er sendt. Den trykte presse behøver ikke længere vente på, at nyheder sker, andre medier programsætter dem for den. Det interessante i receptionsmæssigt perspektiv er, om respondenterne overhovedet skelner mellem den traditionelle slags historier, hvor mediet er viderebringer af nyheder, og den slags hvor mediet selv skaber historierne. 


\section{Det empiriske grundlag}

Jeg har i to fokusgrupper spurgt, hvad det er, der gør Robinson Ekspeditionen godt? Og hvordan forholder kerneseere sig til det medierum, som TV3 har haft held til at skabe med udgangspunkt i programmet. Hvordan forholder seerne sig til iscenesættelsen, og mener de, at de har indblik i, hvad der er fup, og hvad der er fakta, når det handler om begivenhederne på Robinson-øen. Desuden har jeg set på, hvor fascinationskraften ligger i Robinson-konceptet, og om respondenterne afkoder programmet inden for samme tematiske ramme, dvs. om de har samme opfattelse af, hvad programmet handler om. De to fokusgrupper var sammensat ud fra kriterierne, at deltagerne skulle have set min. 10 afsnit af Robinson Ekspeditionen 2000. De skulle i gruppe 1 være mellem 20 og 30 år og i gruppe 2 mellem 30 og 50 år. Ud af $\mathrm{i}$ alt 24 rekrutterede mødte der seks personer op til gruppe 1 og otte til gruppe 2. Fokusgrupperne blev gennemført hos ACNielsen AIM d. 5. december 2000, dagen efter finalen i Robinson Ekspeditionen 2000.

Fokusgruppeinterviewet er valgt som kvalitativ metode, fordi jeg ønsker at fremme kantineeffekten og sætte en diskussion i gang, hvor alles meninger har lige ret. Det forum, som en fokusgruppe danner, giver en ganske særlig dynamik, hvor interessefæller får diskussionen til at udvikle sig frit og uforudsigeligt. Deltagerne får lejlighed til at udveksle meninger og formulere holdninger, som hidtil kun har været latente i deres bevidsthed, men som formuleres eksplicit i mødet med de andres holdninger. Gruppen fungerer dermed også som selvregulerende instans omkring acceptable og uacceptable meninger respondenterne imellem og i forhold til de hypoteser, jeg som moderator fremlægger.

Idet analysens formål er at undersøge, hvordan respondenterne forholder sig til den tv-virkelighed, jeg definerer som iscenesat, har forløbet af fokusgrupperne været formet således, at spørgsmålene har bevæget sig fra de neutrale diskussionsinitierende til de mere hypoteseafprøvende. Dermed er respondenterne først blevet mødt med spørgsmål, som ikke er værdiladede, mens jeg senere har tilladt mig at bevæge mig over mod de mere normative spørgsmål for at provokere respondenterne til at forholde sig til iscenesættelseselementet.

Med det forholdsvis lille antal respondenter kan der ikke for alvor udledes noget om, hvorvidt den yngre gruppe ser Robinson Ekspeditionen på en anderledes måde end den lidt ældre. Når jeg alligevel har valgt at markere citaternes tilhørsforhold, er det for at illustrere, at det måske er de yngre respondenter, der har det mindst romantiske syn på tv, og for kuriositetens skyld!

\section{Fire planer i receptionen af Robinson Ekspeditionen}

Respondenternes umiddelbare associationer på ordene »Robinson Ekspeditionen 2000« bevæger sig i første omgang på fire planer:

1. Det nære plan, hvor respondenterne sidder i sofaen og ser tv.

2. Robinson Ekspeditionen med alt det der foregår i programmet.

3. Et meta-niveau, hvor de reflekterer over det at se programmet.

4. Idéerne om TV3 og deres indflydelse på programmet.

De fire planer for henholdsvis gruppe 1 og 2 ses i nedenstående figur. (Se side 50-51.)

Som det fremgår af de to figurer, er det i høj grad de samme associationer, der udtrykkes i de to grupper. Der er dog en svag tendens til, at gruppe 1, som er aldersmæssigt mellem 20 og 30 år, har større fokus på de ting, der sker omkring programmet, som f.eks. at TV3 kan manipulere med indholdet, end de har i gruppe 2, som var mellem 30 og 50 år. Disse associationer er det umiddelbare udgangspunkt for fokusgruppernes videre diskussion.

\section{Karaktererne i spillet}

Robinson Ekspeditionens præmisser er ganske enkle. Man tager 16 mennesker og sætter dem ud på en »øde« ø. Formålet er at se, hvem der kan blive længst på øen, dvs. undgå at blive stemt hjem af de andre og vinde konkurrencen. For at kunne lave et tv-program har man sendt et kamerahold med, som filmer slagets gang. Robinson Ekspeditionen er som reality-tv en tv-genre, der på en gang tager seeren i ed som usynligt øjenvidne, når begivenhederne filmes, men samtidig gør opmærksom på sig selv som konstruktion via de interviews med deltagerne, der har til formål at holde seeren ajour med spillets udvikling. 
Gruppe 1

\begin{tabular}{|c|c|c|c|}
\hline 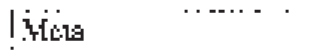 & |TY:S & 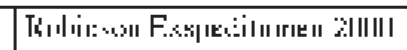 & $\left|y_{1} !\right|: \mid \mathbf{I} n$ \\
\hline 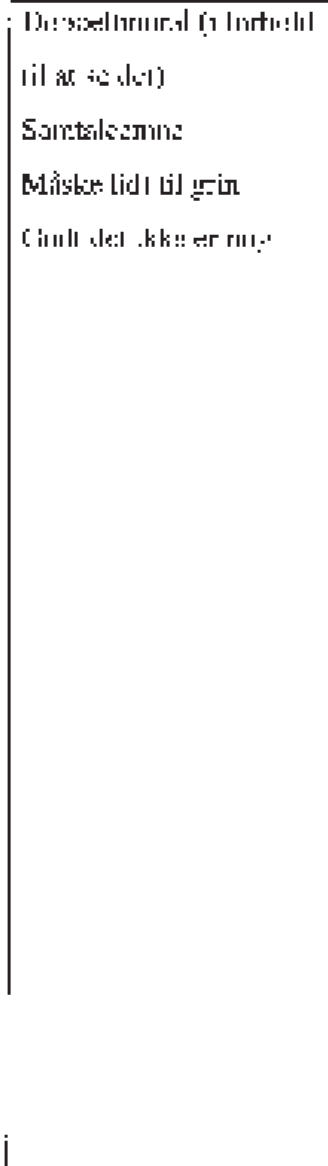 & 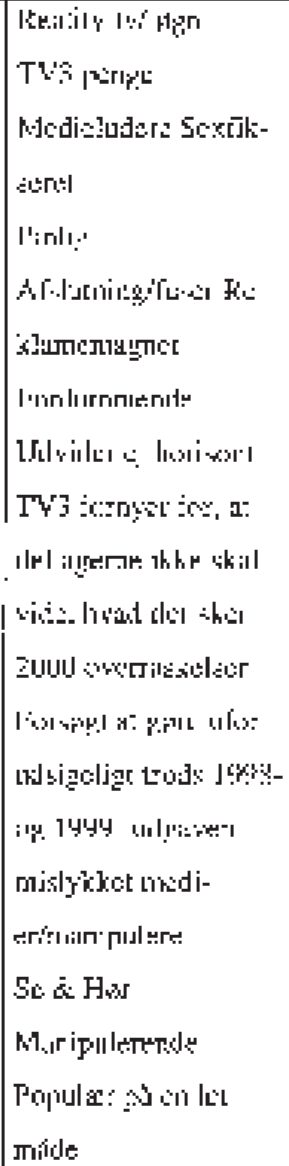 & 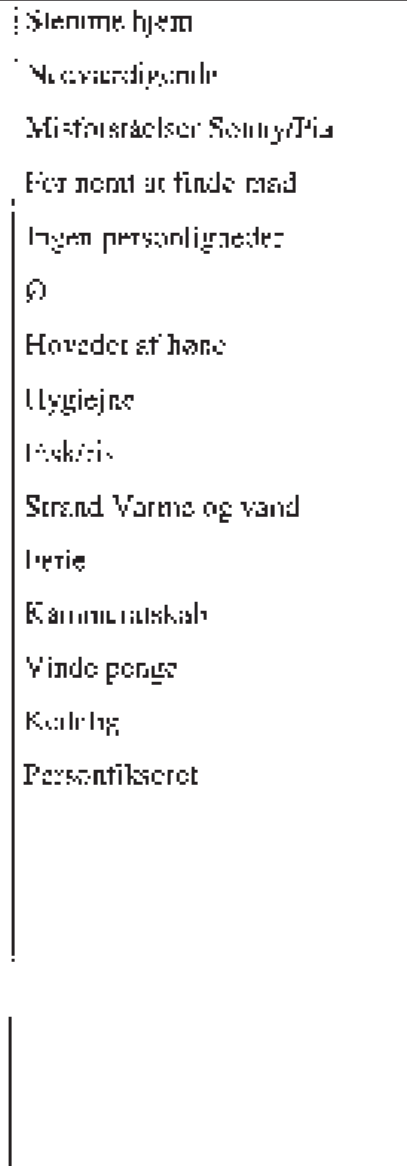 & 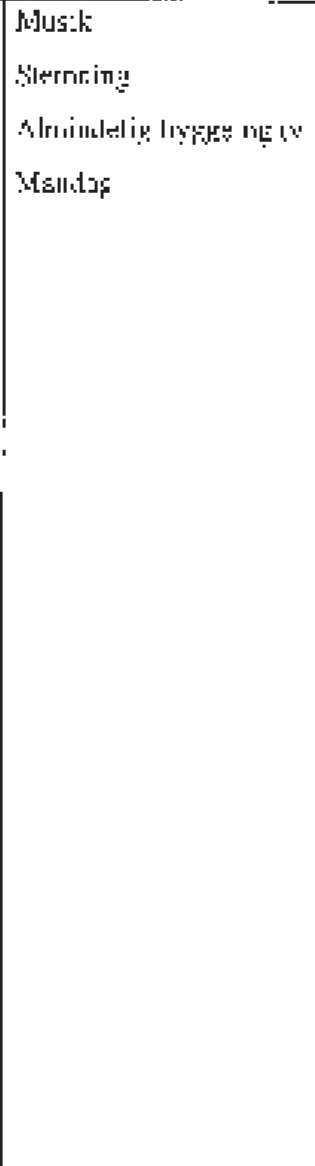 \\
\hline
\end{tabular}

Som seer har man ubevidste antagelser om, hvordan verden hænger sammen - en slags i forvejen definerede mentale skemaer. Skema eller schemata er i forvejen definerede figurer, som indeholder et menneskes samlede viden om et emne. Når man støder på et nyt fænomen sammenligner man automatisk det nye med det gamle, og definerer det nye derudfra. Der redegøres for begrebet schemata hos bl.a. Ralf Pittelkow (1985). Skemaerne kan sammenlignes med sociologen Anthony Giddens' (1984) praktiske bevidsthed og diskursive bevidsthed. Den praktiske bevidsthed er de erfaringer, subjektet har akkumuleret over tid, og som det ubevidst trækker på i sin daglige interaktion med verden. Den diskursive bevidsthed træder derimod i kraft, når subjektet reflekterer over sine handlinger og skal forklare dem eksplicit. Man kan til receptionsanalysen bemærke, at man her forsøger at få respondenterne til, via deres diskursive bevidsthed at gøre rede for deres praktiske bevidsthed! Således ordner seeren også tv-udsendelser, og spørgsmålet er, om Robinson Ekspeditionen med sin blanding af genrer afkodes via et skema, der hører til i fiktionens verdenen eller til i virkeligheden.

Ved tv-skærmen sidder altså en seer og forsøger automatisk at skabe struktur i de informationer, han modtager. Det gør han ved at ordne personer og hændelser efter de skemaer, som er dybt indlejret $\mathrm{i}$ ham via de historier og fortællinger, han historisk og kulturelt er vokset op med. Seerne sætter ubevidst figurerne på plads dér, hvor de per refleks mener, de må høre hjemme. I praksis står TV3 for respondenterne utvetydigt som afsender af Robinson Ekspeditionen, og er dermed den instans der står for den rollefordeling, der er eksplicit i $R_{0-}$ 
Gruppe 2

\begin{tabular}{|c|c|c|c|}
\hline اذابr & $T_{4}=3$ & 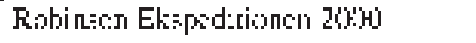 & [ эيl's] \\
\hline 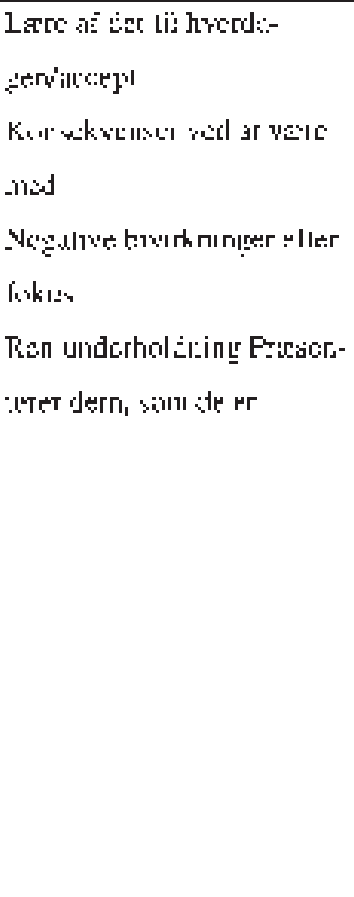 & 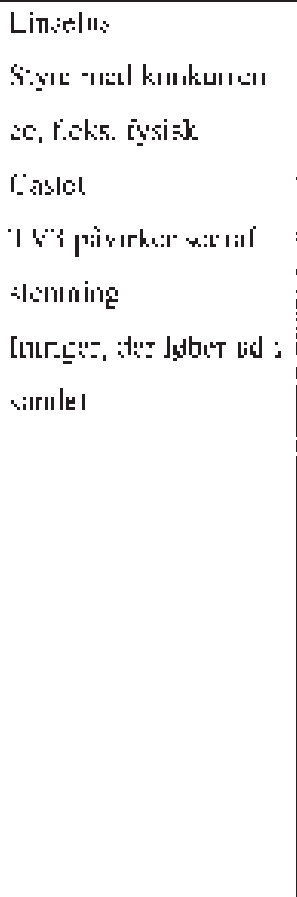 & 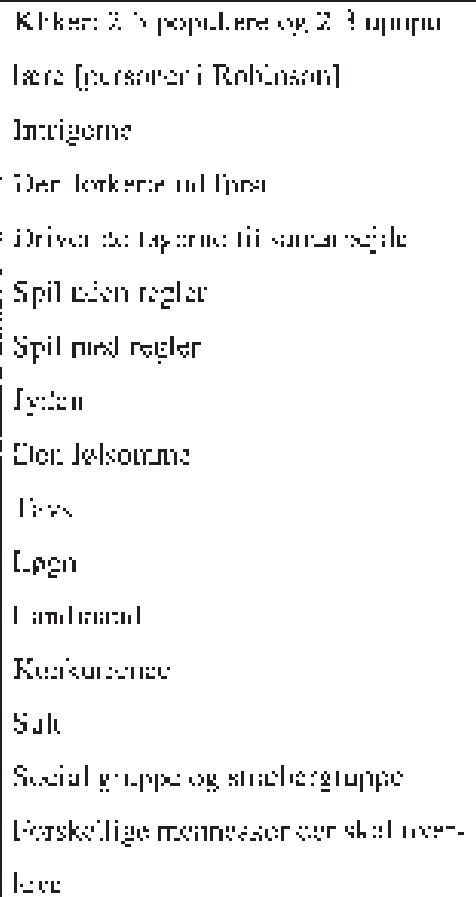 & 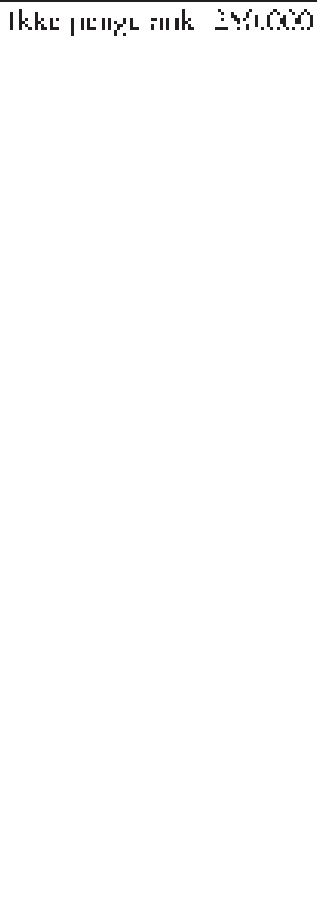 \\
\hline
\end{tabular}

binson Ekspeditionen. TV3 har med deltagerne valgt personer, der ligner de klassiske fiktionsfigurer, som er dybt forankret i vores måde at afkode tekster på. Respondenterne i fokusgrupperne giver udtryk for, at deltagerne i Robinson Ekspeditionen er castet og udvalgt til at udfylde bestemte personligheder.

\section{Gruppe 1}

Moderator: hvordan tror I, man vælger dem ud?

Respondent 1: psykolog

Moderator: hvilken begrundelse har psykologen så for at vælge dem ud, dem der skal med? Der er 7.500 mennesker, der ville være med $\mathrm{i}$ år.

Respondent 2: i Ekstrabladet stod der, at de havde de 16 forskellige personligheder, som de gerne ville have frem, om det så er rigtigt, skal jeg ikke kunne sige, men det kunne man jo forestille sig. Blondinen, det er jo så Pia, så vidt jeg husker, der var styreren, charmetrolden, heksen, sidste år var det nok Janne, der var en rimelig god heks, tilrettelæggeren der prøver at tilrettelægge efter sit eget hoved. Umiddelbart lyder det på mig, som om der ligger et stort arbejde bag.

Respondent 1: jeg synes, også det sagde jeg også derude, at man også kan se, at de prøver at finde de samme for hver gang, altså sidste år var der mange, hvor jeg tænkte, nej det er jo hende og ham. Første gang jeg så Christina, tænkte jeg på Kathleen.

Respondent 3: ja, hun er valgt som den smukke pige, og det var også hende, vi snakkede om, at nej det var jo Kathleen ikke.

Moderator: tror I, de vælger dem til disse bestemte roller?

Respondent 4: ja [almindelig tilslutning til ja]

Moderator: så må der være noget, der er kikset. Man vælger dem til roller, men de har ikke været særlig hidsige denne her gang?

Respondent 3: det, tror jeg, er fordi, de ved, hvad det går ud på, de ved, de ikke skal gå for meget til højre eller til venstre.

Moderator: man skal holde sig midt på stien? 
Respondent 5: men jeg tror også, de vælger meget efter at finde nogle typer, som man måske i det daglige ikke kan gå rundt og tillade sig [...] eller der måske er mange, som føler sig under fra forskellige hierarkiske verdener. F.eks. bare inden for sygehusvæsenet de vælger en overlæge ikke? Og så er det rart at se ham endelig komme ned med nakken. Respondent 1: også en knallertmekaniker ikke? De to er noget af det mest forskellige.

Respondent 5: som så bliver sat stævne på en øde ø, hvor det måske egentlig er knallertmekanikeren, der klarer sig bedst, på en eller anden måde, hvis jeg sad og var knallertmekaniker, ville jeg have det ret fedt med det.

Moderator: er det ligesom man starter forfra, er taget ud af sin egen sammenhæng?

Jette: nej, man er ikke taget ud af sin egen sammenhæng. Det er i forhold til, for seerne at kunne - det er ligesom, hvis der har været en voldtægt, og det er en præst, der har gjort det, jamen så gør det det endnu mere interessant. At få de der typer ind, så er det som om, at hold da op og ham skal vi have respekt for i det daglige og se nu ham der. $\mathrm{Nu}$ går han rundt i sarong og er egentlig lige så menneskelig som os andre. Det tror jeg, at mange mennesker, incl. mig selv, har brug for at se.

\section{Gruppe 2}

Moderator: hvordan tror I, de [vælger deltagerne ud til de to hold], putter de alle navnene ned i en hat, og så siger de: vi har hold syd herovre og hold nord herovre?

Respondent 6: jeg tror, de bruger mange timer på at sidde og planlægge

Respondent 7: de [holdene] er nok sammensat udfra nogle kriterier. Nogle psykologiske profiler for at have både potentielle harmonier, men også konflikter og sympatier, det ligger nok i hele idékonceptet til det.

Moderator: altså?

Respondent 7: ja, der skal være noget, altså hvis det hele er fryd og gammen, så går sådan en udsendelse meget hurtigt af fløjten.

Moderator: du sidder også og nikker?

Respondent 6: jamen jeg sidder også og er overbevist, som du [henvendt til respondent 7] sagde, altså mange af de ting, der foregår, er instrueret. Profilerne er helt klart sat op, og holdene er sat på den måde, de skal være, altså de kan sammen.

Moderator: men hvor meget mere kan man instruere?

Respondent 6: hvad mener du?

Moderator: ja, hvor meget mere kan man instruere 16 mennesker på en øde ø?

Respondent 6: det kan du ikke gøre, du kan kun gøre det der. Resten er op til dem, altså du har ligesom kastet bolden omkring nogle mennesker, der vil potentielt komme op og skændes og toppes på en eller anden måde. Og der vil være nogen alliancer på nogle af dem, der ligner hinanden, og der søger de sammen og finder andre fjender, og det er så dem, der skaber det derfra. Når de er sat dernede, kan TV3 ikke gøre mere.

Respondent 8: de kan lave nogle hårdere konkurrencer.

Respondenterne giver altså udtryk for en udtalt bevidsthed om, at deltagerne er valgt nøje ud. De har også teorier om, hvordan de er valgt ud, genereret af deres egne forestillinger og f.eks. Ekstrabladet. Respondenterne peger på, at deltagerne er tro mod deres egen personlighed, nemlig ved at de ikke er taget ud af deres sammenhæng, dvs. har en anden personlighed end hjemme. Dette er et godt eksempel på det paradoks, der tilsyneladende er i deres afkodning af Robinson Ekspeditionen. På den ene side fortæller de, at det hele er iscenesat, mens de på den anden side mener, deltagerne er loyale overfor deres egen person. Dette er dog på intet tidspunkt problematisk for respondenterne, de ser det som en del af det underholdningsprogram, de definerer Robinson Ekspeditionen som. Definitionen af Robinson Ekspeditionen er klart for de fleste, at det er et underholdningsprogram og et spil. TV3 har altså sat historien i gang; med de klassiske stereotype figurer har man sat brikkerne op på fiktionsformlens skakbræt.

\section{Det serielle sug}

TV3 har sat to hold af spillere, Nord og Syd. Dernæst lader man spilleder Thomas Mygind afbryde opholdets hverdag med de to slags konkurrencer, Kappestriden og Robinson-dysten. Den første lader det ene hold (og når der senere kun er ét hold, 
den enkelte deltager) vinde en præmie, der forsøder livet på øen. Den anden konkurrence tvinger taberholdet til at stemme en holdkammerat hjem. Her kommer vi til en af de ting, som umiddelbart er det, der gør programmet interessant, nemlig hvem der skal stemmes hjem i ugens afsnit og dermed intrigerne. Deltagerne ses i det fælles projekt om at få livet på øen til at fungere, og seerne får ved deltagernes fortælling til kameraet indblik i de interne konflikter. Det er disse klip, der blotlægger intrigerne for seerne. Det enkelte afsnit er klippet sammen, så der bygges op til ø-rådet som klimakset, hvor valget som regel står mellem to personer. I de klip, seerne ser af de forskellige deltageres henvendelse til kameraet, får vi forklaret, hvorfor den ene eller den anden bør stemmes hjem. Det hele er klippet sammen på dramatisk vis.

Højdepunktet ved hvert enkelt afsnit er, hvem der bliver stemt hjem denne gang. Seeren tillades undervejs at regne ud, hvordan de indbyrdes forhold udvikler sig, og ligesådan tillader TV3 seeren at regne ud, hvem der skal hjem og hvorfor. Dermed får seeren lov at sidde med den lille private sejr, det er at regne ud, hvem der står for tur, men helst uden at disse spor bliver for åbenlyse. Disse afsløringsmekanismer redegør Umberto Eco for i artiklen »Fornyelse i det serielle«, hvor han behandler de moderne massemediers serialitet. I artiklen tager Eco fat på serialitetens typologi og rammer med den ned i det spændingsfelt, som Robinson Ekspeditionen 2000 bevæger sig i, nemlig at det er et program bygget op omkring en genkendelig formel, der belønner sin seer med fornøjelsen ved at gennemskue handlingen.

I serien tror brugeren, at han nyder det nye i historien, mens det han i virkeligheden nyder, at se et konstant fortælleskema vende tilbage, samtidig med at det tilfredsstiller ham på ny at møde en velkendt person, der har sine egne tics, sine egne klicheer, sin egen teknik til løsning af problemerne. (Eco 1991)

Serien betrygger sin bruger, fordi den belønner hans evne til at se ud i fremtiden: brugeren glæder sig, fordi han opdager, at han kan gætte, hvad der vil ske, og fordi han nyder at se det ventede vende tilbage. Vi er tilfredse, fordi vi finder det vi havde ventet, men dette »fund« tilskriver vi ikke struktur, men derimod vores egen skarpsindighed og evne til at gennemskue sammenhænge. Vi tænker ikke »kriminalromanens forfatter har sørget for, at jeg gættede det.« Men derimod, »jeg har gættet det, som kriminalromanens forfatter prøvede at skjule for mig.«(Eco 1991)

I den aktuelle sammenhæng føler Robinson-respondenterne ikke, at de er snedige og gennemskuer historien ved at gætte handlingen, før den finder sted, dertil er sporene lagt for åbenlyst ud. Respondenterne giver udtryk for, at de finder serien kedelig og forudsigelig, fordi de ved, hvad der vil ske, f.eks. at der tydeligt bliver lagt op til, hvem der skal sendes hjem i aftenens afsnit! Forklaringen på dette skal findes i, at respondenterne stort set alle har set Robinson Ekspeditionen 1998 og 1999, dvs. de er kendt med konceptet, og trods TV3's anstrengelser for at variere spillet lykkes det ikke helt. Seeren er i dag så kendt med tv'ets mekanismer og muligheder, at afsender skal være mere og mere elegant i opbygningen af historien for at give seeren fornemmelsen af at gennemskue handlingen, før det finder sted, uden at han dog opdager dette kunstgreb. Respondenterne fortæller, at de synes programmet er kedeligere end sidste år og for forudsigeligt.

\section{Gruppe 1}

Moderator: fortæl mig hvad der falder jer ind, når jeg siger Robinson Ekspeditionen 2000?

Respondent 2: kedelig, manipulerende, gentagelse af sidste år - ingen fornyelse, manglende personligheder, reklamemagnet - man sidder og stirrer på de reklamer uafbrudt.

Moderator: er det Robinson eller reklamerne, der er fordummende?

Respondent 2: altså, man udvider jo ikke sin horisont som et godt og rart menneske ved at sidde og kigge på det. Men det er, fordi jeg mener, det er manipulerende.

Respondent 2: trænger til pause, sexfikseret. Pinlig afslutning. Godt det ikke er mig.

Respondent 3: meget anderledes end de andre år - men det er mest fordi, at de mennesker, som har meldt sig, de har - de ved virkelig, hvad de går ind til i forhold til de andre år. Det er meget sådan, de har virkelig, i forlængelse af, at det er lidt forudsigeligt. De [deltagerne] vidste mange af tingene, og så har de [TV3] prøvet at gøre 
det uforudsigeligt for at undgå det - et mislykket forsøg synes jeg.

Seerne har erfaringer fra de tidligere års Robinson Ekspedition, og det samme har deltagerne. Generelt er samtalen omkring Robinson Ekspeditionen 2000 præget af en egen intertekstualitet, hvor respondenterne indbyrdes henviser til personer fra 1998- og 1999-ekspeditionen. Således er der en tydelig tendens til, at respondenterne mener, at Robinson-deltagerne har »lært« af de forrige års ø-ophold. Således vil spillet ændre sig med tiden, selv om udgangspunktet principielt er det samme.

\section{Gruppe 1}

Respondent 2: Du sidder jo og lader dig lyve lige op i hovedet, og de manipulerer med dig. Du tror faktisk på det. Altså det er vi da for kloge til normalt. Altså hvis der kommer en hen på gaden og fortæller dig et eller andet totalt løgn og klipper halvdelen væk, så ville du jo ikke gide snakke med manden. Altså det er det med, at du sidder og ser et eller andet, der bare er klippet efter af en eller anden, jeg ved ikke, hvad sådan en hedder, der sidder og klipper i et tv-studie. Og de bestemmer så, hvad vi skal opleve, og hvad vi skal få ud af de der mennesker. Og det synes jeg ikke er særlig tiltalende. Men jeg ser det alligevel, så jeg forstår udmærket det der med, at det er lidt pinligt. Så sidder man her som voksent menneske og synes, at Robinson det er faktisk sjovt og har set næsten alle sammen, og så deltager man så i et møde [fokusgruppen] om det også ikke!

Respondenterne mener altså, at TV3 har fuld råderet over deres personer og i vid udstrækning har mulighed for at fremstille dem, som de vil. I modsætning til traditionelle tv-underholdningsspil, hvor deltagerne har samme udgangspunkt, når et spil startes på ny, har deltagerne i Robinson Ekspeditionen i større grad end i andre spil kunne drage erfaringer fra de andre år. Jo flere gange spillet gennemføres, jo større vil summen af erfaringer at trække på altså være. Robinson Ekspeditionens deltagere starter ikke længere uden erfaring og viden om, hvad der skal foregå. Respondenterne påpeger, at spillet primært handler om intriger, og om hvem der længst kan undgå at blive stemt hjem af de andre, og det er dette, deltagerne navigerer efter.

\section{Kompetente deltagere og kompetente seere}

Respondenterne definerer ikke Robinson Ekspeditionen som et spil, hvor den stærkeste overlever, men et spil, hvor den, der er bedst til at læse spillet og eliminere sine trusler (stemme medspillere hjem) vinder. Således anses 2000-udgaven af Robinson Ekspeditionen for den hidtil kedeligste. Der har ikke været kamp ${ }^{1}$ nok, deltagerne har været for pæne, og det begrundes til dels i, at de i alt for høj grad har vidst, hvad de gik ind til såvel spil- som mediemæssigt. Således fortæller en respondent, at spilleder Thomas Mygind ikke har haft held til at trække intriger frem i lyset ved de ø-råd, hvor en deltager skal stemmes hjem. De er simpelthen for bevidste om, at det senere i spillet vil blive brugt imod dem. Det er forudsigeligheden, der har præget spillet, og de nye elementer, som respondenten i nedenstående citat refererer til som »tilfældigheder«, der er lagt ind i spillet, får i praksis ikke nogen betydning for dets udvikling.

\section{Gruppe 2}

Respondent 6: det bliver jo også mere og mere underholdning, der bliver puttet mere og mere på ikke, derfor bliver det mere et spil

Moderator: er det mere underholdning nu end før?

Respondent 6: TV3 kommer, altså der skal hele tiden nogle nye ender på, det skal der, for det bliver mere underholdning og spil ikke? Hvor der er kommet flere tilfældigheder ind, end der var i den første.

Moderator: hvordan tilfældighed?

Respondent 6: jamen altså f.eks. det med når folk bliver sendt hjem og så kommer tilbage igen, det er jo en ren og skær tilfældighed, det er jo ikke noget med, altså du har tabt en gang, og så får du en mulighed igen, altså den holder ikke vel [i forhold til overlevelsesaspektet]

Respondent 9: ja det var lidt langt ude [almindelig enighed]

Respondent 6: jo den holder, fordi det skal være underholdning og spil, men reelt så duede det ikke

Der er i begge grupper en særlig konsensus om, 
at Robinson Ekspeditionen har udviklet sig fra noget, der lignede et eksperiment, fordi deltagerne ikke vidste, hvad der skulle foregå til et underholdningsspil, hvor man i forvejen kan træffe sin forholdsregler ved f.eks. at tage fiskenet med hjemmefra. Såvel deltagere som seere har en meget god idé om, hvad spillet indebærer. $\mathrm{Og}$ trods nye tiltag, som det at sende hjemsendte ind i spillet igen, lykkes det ikke TV3 at gøre spillet mere spændende.

\section{Autenticitet og virkelighed}

Autenticitet eller virkelighed - hvad der er sandt eller falsk i iscenesættelsen af Robinson Ekspeditionen er ikke noget, der betyder særlig meget for respondenterne. De er bevidste om det, men det har ingen indflydelse på deres mening om programmet som godt eller dårligt. Der er tendens til, at gruppe 1 er de mest bevidste med hensyn til iscenesættelse.

Respondent 4: der vil jeg sige, at der synes jeg netop også, at det skal TV3 have allermest ros for. Fordi vi ved jo godt, at det er konstrueret. Men de formår fandeme at fremstille det i høj grad sådan, at jeg i hvert fald, når jeg sidder og ser det, ikke tænker, nåh ok det er konstrueret. [Almindelig enighed].

Respondenterne nærer, i forlængelse af diskussionen om roller, ikke nogen illusioner om tilfældighedernes spil. I gruppe 1 mener en respondent, at TV3 kender deltagernes personlighed så godt, at de kan forudsige reaktioner på de forskellige konkurrencer og måske dermed puste lidt til ilden omkring intrigerne. Gruppe 2 er langt mindre eksplicitte omkring dette og mener, at konkurrencerne blot kan udskille folk af spillet generelt, fordi de skiller de fysisk svage ud.

Som citatet ovenfor illustrerer, så forventer respondenterne ikke et eksperiment, selvom det til dels er det, der lægges op til fra TV3's side. Seerne er godt tilfredse med det underholdningsprogram, de definerer Robinson Ekspeditionen som at være. Respondenterne refererer som nævnt flittigt til de foregående års ekspeditioner, og der er enighed om, at konceptet har udviklet sig fra noget, der var mere eksperimentagtigt hen i mod et spil. Der er en udbredt opmærksomhed på, at begivenhederne kan være iscenesat, men det er ikke et vigtigt element i diskussionen, det har ikke for alvor nogen indflydelse på, hvorvidt programmet anses for at være godt eller skidt, sandt eller falsk. Det bemærkelsesværdige er, at Robinson Ekspeditionen ikke på noget tidspunkt har haft status som et socialt eksperiment. Det eksperimentagtige ligger i, at hverken seere eller deltagere de første år vidste, hvordan spillet ville udvikle sig, og hvad en Robinson Ekspedition overhovedet var. Eksperimentet foregår dermed på tv's præmisser - der er opstillet nogle, på det tidspunkt ukendte, regler for, hvad deltagerne vil komme ud for. Men ingen definerer spillet som et socialt eksperiment, hvor tv blot er tilskuer. Tv er en aktiv medspiller i Robinson Ekspeditionen. Respondenterne er samtidig overbeviste om, at deltagerne har haft flere grunde til at melde sig til Robinson Ekspeditionen, bl.a. fordi de øjner en chance for berømmelse. Se f.eks. ord som »linselus« og »medieludere« i figur et og to.

\section{Gruppe 1}

Respondent 4: så tænker jeg også på medieludere, jeg har en ide om, at der er flere af dem, der er med i år, de har decideret meldt sig for at blive den nye Kathleen, altså jeg har indtryk af, at de, der har meldt sig, simpelthen har ønsket om at blive medieludere ikke. Så har jeg også, at det igen er dobbeltmoralsk [i forhold til det at se Robinson], at jeg ser det som, utroligt spændende, interessant, jeg ser det som real-time tv eller reality-tv på en eller anden måde, selvom det er en stor løgn det hele.

\section{Gruppe 2}

Respondent 6: der er jo en lille linselus i alle dem, der melder sig på en eller anden måde, så derfor er pengene fuldstændig ligegyldige i den forbindelse, om det er 250.000,- eller hvad det er, er lige meget, større beløb vil bare få flere til at melde sig.

Med henvisning til at tidligere års deltagere i $R_{0}$ binson Ekspeditionen senere har opnået berømmelse som tv-værter, f.eks. den fra TVDanmark berømte Biker-Jens, nævner respondenterne uhjulpet, at der er tale om, at det er attraktivt for deltagerne at være med i Robinson Ekspeditionen, fordi man er sikret en form for berømmelse. Man kan ifølge respondenterne godt lukrere (økonomisk) i at have været med i Robinson Ekspeditionen. 


\section{Fascinationskraften}

Klaus Bruhn Jensen (1985) arbejder med begrebet supertemaer ${ }^{2}$, hvormed han mener at kunne tilbagevise seerens magt til at afkode programmerne, som han eller hun selv ønsker. Dvs. indlæse den mening seeren ønsker, at programmet skal indeholde. Dette eksemplificerer han ved at identificere bestemte temaer som gennemgående i amerikansk tv. Når det handler om supertemaer inden for den smalle ramme, som Robinson Ekspeditionen er, så er det udefra betragtet et modsætningsfyldt spil: det endelige mål er sejren for den enkelte, dvs. at være den eneste tilbage på øen, men midlet til at vinde er at klare sig gennem samarbejdet med de andre deltagere på først to, siden ét hold. Ud fra en umiddelbar betragtning er filosofien i Robinson Ekspeditionen, at enhver er sin egen lykkes smed.

For respondenterne ligger fascinationskraften i Robinson Ekspeditionen primært ét sted, nemlig i det autentiske islæt og det faktum, at det er rigtige mennesker af kød og blod, der går rundt på øen. Respondenternes opmærksomhed på, at man som seer ikke kan vide, hvad er sandt eller falsk, betyder ikke noget i denne forbindelse.

Respondent 3: det er en slags reality-soap, og så er det virkeligheden, der er gjort til en god historie, ligesom vi snakkede om, at når jeg ser en god film i fjernsynet, og der står, at det er bygget på en virkelig begivenhed, så er jeg også lidt mere årh, selvom det måske er en lille bitte brøkdel af det.

Uanset hvor iscenesat Robinson Ekspeditionen er, er det stadig rigtige mennesker, der går rundt på en rigtig ø, som en af respondenterne siger. De virkelige mennesker er det afgørende element ved Robinson Ekspeditionen. Der er dog forskelle i de to gruppers afkodning af, hvad der er den væsentligste fascinationsfaktor ved udsendelsen. Blandt de 20 til 30-årige i gruppe 1 er man udtalt opmærksomme på, at det er noget grænseoverskridende rent personligt og psykisk, der holder dem fast ved skærmen. Således finder de, at det er virkelige hændelser og derfor i sig selv mere interessant, end hvis det er ren fiktion.

\section{Gruppe 2}

Respondent 10: der er så meget fiktion i fjernsynet i dag. Det er meget film, film, film hvor man laver en historie, og så blæser man det op, fordi det virkelige liv godt kan være lidt kedeligt. Her virker det som om Robinson, det er rigtige mennesker, og de er rigtigt på denne her ø, og der står ikke et stort hotel på den anden side, hvor de går over og spiser.

For en stor dels vedkommende er det grænseoverskridende element i Robinson Ekspeditionen det, der gør det dragende. Deltagerne bliver skubbet en lille smule mod den psykiske grænse og stilles til ansvar for deres handlinger på en måde, som man normalt ikke bliver. Det er den almindelige opfattelse af, hvad der etisk korrekt at gøre mod andre mennesker, der pludseligt bliver udfordret på tv, f.eks. fortæller andre, at det er det »pinlige« i situationen, og det at man kan tillade sig at blive forarget over deltagernes handlinger og udtalelser, der holder dem fast ved skærmen.

\section{Gruppe 1}

Respondent 2: det er sjovt at sidde og være hjemmepsykolog. [...] man bliver manipuleret, og så sidder man hjemme i sofaen og manipulerer det en gang til og lægger lige en ny betydning til om, hvorfor de gør det, altså det er sjovt at sidde og få lov til at analysere andre mennesker, alle deres negative og gode sider, man sidder og rakker dem ned eller roser dem. Specielt det negative, det er jo sådan noget, man kunne frygte, andre mennesker gjorde ikke ved en selv ikke. Tog ens personlighed og skar den i tynde skiver og kom med en kommentar. Det hører også til det grænseoverskridende ikke.

Respondenten i ovennævnte citat rammer præcist, hvad det er, der fascinerer så mange; at det er almindelige mennesker, modsat skuespillere, der bliver fremstillet med dertil hørende menneskelige svagheder og styrker, men det er ikke en selv, der bliver ramt. Og fordi det er på tv, har man i princippet lov og ret til at gøre sig til psykolog og dommer over andre menneskers handlinger på en måde, som vil være socialt uacceptabel i det virkelige liv. Det giver et kick, synes respondenterne, dette at det er det virkelige liv. Indlevelsesmuligheden er eksplicit et vigtig punkt i gruppe 1; at man følger de samme personer fra afsnit til afsnit og følger med i deres udvikling som personer i historien.

Der er samtidig enighed om, at Robinson Ekspedi- 
tionen er »the original« i sin genre. TVDanmarks Villa Medusa og Baren og Big Brother er blot nye efterlignende eksempler i genren. Men Baren og Big Brother anses dog for at have den funktion, at de blot udvider grænserne for, hvad man kan og ikke kan.

\section{Gruppe 1}

Respondent 5: og nu har vi ligesom haft de der to år til at vide, hvad det [Robinson Ekspeditionen] er ikke, og når vi så ser det nu, så bliver vi næsten utilfredse. Det var altså ikke groft nok. Kom med noget mere ikke. Altså at vi på den måde, hvis vi lige tager tilbage til det grænseoverskridende, har fået flyttet nogen grænser for, hvad der er tilladt at gøre i tv. Og det var altså bare for pænt.

Respondent 4: [henvendt til respondent 5] det er også derfor, at vi skal videre, ikke, til Baren og Big Brother, fordi de går tanden videre ikke?

I gruppe 1 er afkodningen af programmet entydig, det handler om at flytte grænser og om, at det er virkelige mennesker på tv. I gruppe 2 nærmer man sig samme definition om end fra lidt flere synsvinkler og mindre udtalt. Ikke desto mindre er de 30-50-årige i gruppe 2 enige om, at det gode er bevidstheden om, at det er virkelige mennesker på skærmen, og at virkeligheden overgår fantasien. Men i gruppe 2 er man også i højere grad tilbøjelig til at inddrage identifikationsmekanismen i, hvorfor man synes Robinson Ekspeditionen er en god udsendelse.

\section{Gruppe 2}

Respondent I 1: Det er det menneskelige i det, hvor man kan drage paralleller til hverdagen. Alle de der mennesketyper og reaktioner mellem de forskellige mennesker. Sådan er det også i den virkelige verden

Flere mener f.eks. at man kan bruge deltagernes måder at tackle problemerne på øen på til at tackle problemer i sin egen hverdag. F.eks. er samarbejde et vigtigt emne. Det er et eksempel på ens arbejdsplads, hvor man skal fungere trods forskelligheder i personlighed. Samarbejdet ses i flere versioner f.eks. som en iboende modsætning $i$ intrigerne, som, der er konsensus om blandt de fleste af respondenterne, er det, Robinson Ekspeditionen egentlig handler om. I modsætning til dette giver en respondent udtryk for, at hun ikke bryder sig om disse intriger.

\section{Gruppe 2}

Moderator: hvad er det, der holder dig fast?

Respondent 12: jamen det er det er for at se så mange forskellige mennesker, hvordan de kan overleve sammen

Moderator: ja?

Respondent 6: men det er vel også intrigerne ikke?

Respondent 12: jo, men jeg bryder mig ikke om at høre på det der, altså jeg kan godt finde på at rejse mig og gå, når det bliver for voldsomt, og når de simpelthen sviner hinanden til. Det synes jeg er lige i overkanten ikke.

Pågældende respondent bruger altså programmet på en helt anden måde end flertallet, der anser intrigerne for at være det afgørende tema i programmet. Respondenten er eksponent for den afkodning af programmet, der mener, at man, som en del af dette at drage paralleller til deres eget liv, også kan lære noget af programmet. F.eks. om dyrelivet på øen eller hvordan man bruger de forhåndenværende midler til at bygge hytter etc. Afgørende er imidlertid stadig, at det er »rigtige mennesker på en rigtig ø巛.

Konfronteret med deres egne udtalelser om, at det er iscenesat, og at deltagerne har roller, finder respondenterne ikke, at der er noget modsætningsforhold, idet det jo stadig er levende mennesker, der udgør spillet på øen. De vigtigste temaer rent afkodningsmæssigt i Robinson Ekspeditionen er altså på programplanet samarbejde og parallellerne til eget liv. Men mere overordnet er det væsentligste den eksplicitte bevidsthed om, at det er virkelige mennesker, der tilskikkes disse begivenheder.

\section{Medierummet}

Samtidig med Robinson Ekspeditionens udsendelse på TV3 er der i andre medier bygget et særligt medierum, når det handler om Robinson Ekspeditionen. I dette medierum optræder deltagerne fra dette og tidligere års ekspeditioner som berømtheder. Dermed er det et godt eksempel på, hvordan medier kan gøre en konstrueret begivenhed til en 
nyhedshistorie. Robinson Ekspeditionens deltageres berømmelse er forskellig fra andre menneskers berømmelse, idet den er omvendt. Hidtil har mennesker, som har et særligt talent - f.eks. en idrætsudøver, en skuespiller eller forfatter fået plads i medierne, fordi de har foretaget sig noget specielt beundringsværdigt, f.eks. skrevet en bog eller vundet en fodboldkamp. Med Robinson Ekspeditionens deltagere er det interessante ved dem, at de i første omgang er blevet berømte ved at være i tv, uden at have andre talenter end de, der kræves for at være med på Robinson Ekspeditionen. Eksemplerne på idrætsstjerner, der er blevet sportsjournalister, siden journalister og underholdningsværter, er talrige. For disse gør det sig altså gældende, at de har et særligt talent og derudover er egnede til at begå sig på tv. Med Robinson Ekspeditionen og reality-tv arbejdes der omvendt. Man caster de fascinerende almindelige mennesker, sætter dem ud på en øde ø og laver et tv-program om deres strabadser. Derefter bliver de berømte, og først der træder de ud af Robinson-verdenen og over i det medierum som f.eks. Ekstrabladet, BT og Billede Bladet etablerer omkring dem, for til sidst at ende som tv-værter på andre kanaler. Dermed smelter medierummet og det offentlige rum sammen, som det illustreres i nedenstående figur.

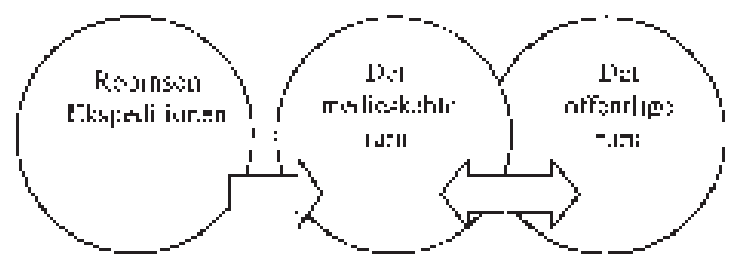

Den mest omtalte og succesfulde må vel siges at være »Biker-Jens«, der efter deltagelsen i Robinson Ekspeditionen er blevet rejseguide i TVDanmarks programmer og med et kamerahold i hælene har rejst over flere kontinenter. TV3 formår altså med deres programs deltagere efterfølgende at komme til at dominere andre tv-kanaler og såvel dagssom ugepressen. Dette medierum er det som Lars Kjerulf Petersen beskæftiger sig med i artiklen »Hvad er mediesociologi?«:

Der er en verden af tegn som bliver transmitteret af medierne, en virtuel verden af billeder, lyde og bogstaver, som lever i de elektroniske signaler $(\mathrm{og}$ vel også i de trykte formater). Det er en virtuel, men ikke uvirkelig verden, for den indgår i ska- belsen og indretningen af sociale virkeligheder, og som virtuel verden står den i forbindelse med den fysiske verden. (Kjerulf Petersen 2000)

Dette skel mellem den virtuelle verden, altså det medieskabte rum, og den fysiske oplever respondenterne ikke. De opererer kun med et rum, det offentlige, fælles tilgængelige. Den verden, hvor de skaber betydning, er kun én, og hvorvidt begivenhederne stammer fra den ene eller den anden kant er mindre vigtigt. Respondenterne tilskriver markedsmekanismerne indflydelse på dette, at historier bliver skabt ${ }^{3}$. Helt specifikt har ugebladet $\mathrm{Se} \& \mathrm{H}$ or betalt en rejse til Paris for en af deltagerne, således at han kunne fri til sin kone der, sådan som han havde fortalt i en af udsendelserne, at han gerne ville. Dette anser respondenterne for at være helt i sin orden, det er op til den enkelte, hvad han vil være med til. Det er især i gruppe 2 anset som »ækelt«, at ugebladene laver deres historier på denne måde, men det er acceptabelt, så længe den enkelte person selv har afgjort, om han vil være med.

\section{Gruppe 2}

Respondent 11: men det er jo Anton, der vælger det der. Jeg synes altså, hvis ser man det ud fra en virksomheds synspunkt, jamen hvis Se \& Hør scorer penge på at give ham et eller andet antal kroner til at sende ham til Paris, og de scorer penge på det [...] det kan jeg godt se ud fra en virksomheds tanke, det synes jeg da er fedt nok. Hvis Anton og hans kone vil stille op til det så lad dem, og hvis nogle gerne vil købe bladet, må de om det. Det er da okay.

Respondent 10: der er ingen, der har tvunget dem

Respondent 9: det er den der nøglehulseffekt, nysgerrigheden efter at se andre mennesker osv. Nogen gange er det bare enormt ubehageligt, at det sker på bekostning af andre, og det bliver ubehageligt. Men andre gange kan det være noget godt. Sådan er det jo med sådan noget Robinson og Se \& Hør, nogle gange er de stride og tjener penge på et billigt trick

Det, respondent 9 her påpeger som »nøglehulseffekten«, er det samme som en anden respondent refererer til, da hun skal forklare eks-robinson- 
deltagernes popularitet efter, at de er trådt ud i det offentlige rum. Nemlig det, at seeren med tv har været med backstage i deltagernes liv, og på den måde bliver robinson-deltagernes erfaringer til respondenternes erfaringer.

\section{Gruppe 2}

Respondent 10: så vil folk vælge Biker-Jens, fordi ham kender vi, for vi har lidt fulgt ham i tykt og tyndt [respondenten eksemplificerer Biker Jens som valgmulighed sammenlignet med en mere spændende, men ukendt foredragsholder]

Moderator: kender man ham bedre end man ville kende en forfatter som Jane Aamund, der skulle holde foredrag?

Respondent 11: ja for det gør man jo, for du rammer bredt i befolkningen med den udsendelse, fordi jeg tror, at det er alle fra 5-6 år og til 99, der ser sådan en udsendelse ikke? [...]

Respondent 10: det er fordi, man har set ham gøre ting, man har fulgt med. Jane Aamund har man set $\mathrm{i}$ interviews og måske hørt til foredrag og måske læst hendes forfærdelige livshistorie. Det er som om, hende har du ligesom kun øre til, mens Biker-Jens har man både øjne og ører til, og der tror jeg det visuelle gør en stor forskel

Kjerulf Petersen behandler i sin artikel netop dette, at erfaringerne skifter karakter. Men pointen er her, at deltagerne ikke bemærker det - den effekt, at det er som at have været der selv, træder stærkt i kraft:

Igen vi kender og deltager i verden ved hjælp af medierne, men mere end det, så kommer medierne til at danne et selvstændigt erfaringsunivers. Man lever i fortællingernes verden, man har et forhold til karaktererne i fjernsynsserier, man befinder sig på nettet. Sekundære erfaringer får status om primære. (Kjerulf Petersen, 2000).

Men som seer er man vidne til et univers, der kun eksisterer i kraft af sin iscenesættelse på tv. Det er, som Kjerulf Petersen påpeger, ikke længere medier, der formidler (andres) erfaringer til os, men mediet, der selv skaber erfaringer og inddrager seeren i disse. Men tv er så tilstedeværende og virkeligt, at disse sekundere erfaringer får status som primære. Det at man har set nogen bygge hytter giver seeren erfaring i den retning, og det, at man ser mennesker reagere på en bestemt måde, skaffer seeren viden om dette reaktionsmønster. Disse tv-formidlede erfaringer giver altså seeren nogle nye kompetencer.

\section{Den dobbelte kontrakt}

Normalt indgår en afsender af en tekst (aviser, noveller, radiospil, tv-aviser, eventyr etc.) en uudtalt kontrakt med sin modtager om, hvorvidt det følgende er sandt eller digtet. Poul Behrendt påpeger i artiklen »Med to hoveder « en stigende tendens i litteraturen til en såkaldt dobbeltkontrakt. Den går som regel ud på, at det følgende er løgn, men det kunne være sandt, og henviser her til bl.a. politikerbiografier, hvor forfatteren ikke nødvendigvis har talt med hovedpersonen, men forlader sig på andre kilder og finder selv på resten ${ }^{4}$. Normalt arbejder man med virkelighedskontrakten og fiktionskontrakten, altså den dokumentariske virkelighed, som i f.eks. tv-avisen eller et dokumentarprogram eller fiktionen, som i en tv-serie eller i en film. Robinson Ekspeditionens succes ligger i, at man har formået at markedsføre virkelighedskontrakten, men i virkeligheden leverer en fiktionsvare. Der er ikke noget manuskript, og det er ikke skuespillere, men almindelige mennesker. Altså må det være fakta. Men programmet er stærkt redigeret, forløbet er styret af konkurrencer og holdleder, derfor er det en stærkt styret virkelighed. TV3 har altså med succes indgået en dobbeltkontrakt med sine seere omkring Robinson Ekspeditionens sandhedsværdi. På den måde har man lov til at benytte det bedste fra alle verdener. Spørgsmålet er som altid, hvor meget vi som seere bliver tilladt at se, men dette plager ikke respondenterne, så længe det er underholdende tv.

\section{Så længe det underholder}

Robinson-seeren oplever ikke noget modsætningsforholdiblandingen af virkelighed og konstruktion. Hvorvidt det er gennemskueligt eller ej, hvad der er virkeligt og hvad der er iscenesat er lige gyldigt i denne sammenhæng. Dét er det, fordi formålet - at lave et godt tv-program - opfyldes. Respondenterne definerer entydigt Robinson Ekspeditionen som underholdning, det er altså fjernt fra sociale eksperimenter og dokumentar. Dermed kommer de behændigt uden om at skulle tage stilling til, om det er rigtigt eller forkert at blande virkelighed 
og løgn, idet de med underholdningsdefinitionen samtidig påpeger, at på underholdningsfeltet betyder det ikke noget, hvad der er sandt og falsk. Programmet udvikler underholdningstrækkene ved at indsætte det, respondenterne kalder »tilfældigheder ${ }^{5}$, dvs. styrer spillet med elementer, som ikke er naturlige i en kamp for overlevelse. Dermed fjernes illusionen om overlevelse på en øde ø yderligere, og TV3 tillader Robinson Ekspeditionen i højere grad at blive at blive et spil.

Alligevel er de afkodningskompetencer, som træder i kraft hos seerne knyttet til de skemaer, der hænger sammen med fakta og sandhed. Det gør de i kraft af, at det er virkelige mennesker, der optræder, og dette faktum er langt vigtigere i afkodningen, end det er, at alt andet kan være iscenesat. En anden vinkel på det er, at ved deltagelsen af virkelige mennesker bliver programmet virkeligt og autentisk i sig selv, det skaber så at sige sin egen sandhed.

Accepten af iscenesættelsen skal ikke ses som en nødtvungen accept af, at målet helliger midlet, for pointen er, at det simpelthen ikke gør noget. Seerne anser det for programmets præmisser, at de ikke ved, hvad der er sandt eller falsk, noget der kun i ringe grad optager respondenterne. Respondenterne og seerne er, især for den yngre gruppes vedkommende, vokset op med tv og har derfor nogle velsmurte afkodningskompetencer, som gør, at de problemfrit navigerer mellem tv- genrerne, fiktion såvel som virkelighed.

\section{Det virkelige menneske i medierne}

Robinson Ekspeditionens seere er meget loyale og har deres helt eget sprog omkring programmet. Respondenterne i fokusgrupperne manøvrerer behændigt rundt i personer og begivenheder fra alle tre års udgaver af Robinson Ekspeditionen, uden at de på noget tidspunkt mister overblikket. Der er stærke intertekstuelle referencer frem og tilbage. Ingen behøver at definere intriger og alliancer, fordi alle taler robinson-sproget og ved, hvad disse ord indebærer. Robinson Ekspeditionen 2000 får skudsmålet kedelig. Som nævnt har seerne velsmurte afkodningskompetencer, og disse er undervurderet fra tilrettelæggernes side. Robinson Ekspeditionen er som tv et æstetisk flot værk. Men det Eco (1991) omtaler som at lade læseren regne ud, hvad der sker næste gang, er for åbenlyst re- digeret sammen. Det er så tydeligt i hvert afsnit, hvem der skal stemmes hjem, at seeren slet ikke behøver at prøve at regne det ud. Det er ganske enkelt lagt foran ham, og det keder ham.

Seerne forholder sig ikke eksplicit til det medieskabte rum. For dem eksisterer kun det fælles offentlige rum, og det er ikke væsentligt, hvorvidt aktørerne stammer fra fjernsynet eller fra virkeligheden. Der er bevidsthed om, at nogle historier er medieskabte (jf. Se \& Hør-historien), men dette er som nævnt ikke vigtigt, og det er noget respondenterne tilskriver markedsmekanismerne. Der er en fælles antagelse om, at det handler om at tjene penge, primært for TV3, og sekundært for de medier, der skriver om de kendte personer. Således bliver det til et spørgsmål om, hvorvidt den enkelte person vil lægge ryg til historien. Det er en nøgtern økonomisk analyse af, hvem der i sidste ende har udbytte af det.

\section{Erfaringernes möbiusbånd}

Robinson Ekspeditionen har sin styrke i de virkelige mennesker og $i$, at seeren får lov at følge dem på skærmen og videre ud i den fælles offentlighed. Idet seerne har erfaringer tilfælles med deltagerne ${ }^{6}$, bliver det nemmere for dem at identificere sig med dem som personer på den offentlige scene. Deltagernes erfaringer er seernes erfaringer - vi var der (så det) jo selv. Dermed har vi, som Kjerulf Petersen påpeger, ikke længere medier, der formidler (andres) erfaringer til os, men medier der selv skaber erfaringer og formidler dem til seeren. I yderste konsekvens vil seeren altså ikke længere skelne mellem sekundere og primære erfaringer. Det er som et möbiusbånd med to slags erfaringer, hvor man ikke for alvor kan se, hvor den ene side fører over i den anden, og det er ikke muligt at skelne mellem primære og sekundere erfaringer. Interessante perspektiver for dem, som forstår at udnytte dem.

\section{Noter}

1 Således mener andre respondenter, at spillet har været for let, idet deltagerne har haft for let adgang til mad. De har ikke sultet nok!

2 Bruhn Jensen arbejder i praksis her med opfattelsen af flow og spørgsmålet om, hvem der dybest set har magt over ind- og afkodningen af tv. Men selve temabegrebet finder jeg anvendeligt også på det mere nære programplan, hvor man taler om Robinson Ekspe- 
ditionen. Det er nemlig et redskab, hvor det er muligt at undersøge, om respondenterne dybest set har afkodet programmet sådan, at de har samme opfattelse af, hvad det handler om.

3 I praksis præsenteredes et specifikt eksempel i fokusgrupperne. Nemlig at Robinson Ekspeditionens Anton i udsendelsen havde fortalt, at vandt han de 25.000 kroner (som en af de 4 sidste på øen) ville han invitere sin kæreste til Paris og fri til hende der. Ugen efter, at det blev kendt, at Anton blev stemt hjem, optrådte han i Se E Hør på knæ foran sin kone med Eiffeltårnet i baggrunden. Se \& Hør havde betalt rejsen til Paris for Anton og fik dermed lejlighed til at få frieriet fotograferet på nærmeste hånd.

4 En sløring mellem sandhed og digt er ikke ny, påpeger Behrendt og bruger Klaus Rifbjergs »Spinatfuglene« som eksempel på fiktion, der læses med størst udbytte, såfremt man kender til de virkelige personer og begivenheder, som er forlæg for bogen.

5 »Tilfældigheder« er, at man sender en deltager tilbage i spillet, efter at denne er stemt hjem og dermed forstyrres spillets naturlige udvikling.

6 Som en respondent udtrykker det, har vi været med hele vejen gennem både slut og tørst.

\section{Litteratur}

Behrendt, Poul (1997): »Med to hoveder « in Weekendavisen d. 24-27. oktober 1997

Eco, Umberto (1991): »Fornyelse i det serielle« in Om spejle, Gyldendal 1991

Giddens, Anthony (1984): The Constitution of Society. Polity Press

Jensen, Klaus Bruhn (1991): »Flow, Tv-reception, Magt og Mening « in Jens F. Jensen (red.), Analyser af to og tvkultur, Medusa.

Jerslev, Anne (2000): »Virkeligheden bag Robinson« in Universitetsavisen, no. 19

Petersen, Lars Kjerulf (2000): »Hvad er mediesociologi« in Dansk Sociologi no. 212000

Pittelkow, Ralf (1985): »Seernes tv-avis« i Ralf Pittelkow (red.), Analyser af tv, Medusa 1985

Birgitte Knudsen er Moderator på ACNielsen AIM A/S 